\title{
Tonalność języka w pieśni na podstawie utworów ludu Sui
}

\section{Speech tones in songs: a case study in songs of Sui people}

\author{
Hanna Kupś \\ CENTRUM JĘZYKA I KuLTURY ChIŃSKIEJ, UnINERSYTET MIKOłAJA KOPERNIKA WTORUNIU \\ UL. FOSA STAROMIEJSKA 3, 87-100 TORUŃ \\ hanna.kups@gmail.com \\ Kamil Burkiewicz \\ KATEDRa ORIENTALISTYKi, UniWERSYTET IM. AdAMA MickieWiCZA W POZNANIU \\ UL. 28 CZERWCA 1956 198, 61-485 POZNAŃ \\ kamil@burkiewicz.pl
}

\begin{abstract}
This article aims at describing the realization of lexical tones in songs of Sui people. The main focus for research are the drinking and mountain songs, a part of Sui's abundant oral literature, most commonly used during traditional festivities and social gatherings. The paper starts with the presentation of the state of current research and the description of Sui language and music. What follows is analysis of four Sui songs and conclusions. The methodology of the article is mostly based upon previous accomplishments, in eg. Chan 1987 and Wong \& Diehl 2002.
\end{abstract}

Zależność pomiędzy tonalnością leksykalną a linią melodyczną pieśni wzbudza coraz większe zainteresowanie językoznawców i muzykologów. W centrum uwagi badaczy znalazły się głównie wybrane języki afrykańskie oraz azjatyckie, m.in. chińskie i tajskie. Celem niniejszego artykułu jest weryfikacja podstawowych wniosków badawczych dotychczasowych publikacji na przykładzie pieśni ludu Sui (水 Shuǐ, [sui ${ }^{3}$ ]) oraz przybliżenie zachodniemu odbiorcy elementów rzadko opisywanej przez świat naukowy tradycji muzycznej. Opracowanie podzielone jest na trzy zasadnicze części. W pierwszej, wprowadzającej, określono stan badań dotyczących relacji pomiędzy tonalnością języka a linią melodyczną pieśni, 
a następnie zarysowano charakterystykę ludu Sui, najważniejsze cechy fonologiczne jego języka oraz klasyfikacje i strukturę pieśni ludowych. W części drugiej przeanalizowano tzw. efekty strukturalne w czterech pieśniach biesiadnych i górskich, które zostały następnie skontrastowane z wnioskami płynącymi z wcześniejszych badań. Artykuł zamyka podsumowanie, zawierające sugestie dotyczące kierunków dalszych rozważań, które mogłyby pogłębić rozumienie skomplikowanej relacji pomiędzy językiem a muzyką.

Autorzy pragną wyrazić serdeczne podziękowanie dyrektor Muzeum Kultury Powiatu Sandu (三都文化館 Sāndū Wénhuàguăn), pani Shi Yuqiu

(石玉秋 Shí Yùqīu), za udostępnienie korpusu pieśni Sui, panu Wei Shuqi ${ }^{1}$, wykonawcy zapisu tekstów utworów, oraz panu Jerzemu Fryderykowi Wojciechowskiemu² za sporządzenie transkrypcji głównej linii melodycznej utworów. Wszystkie tłumaczenia zawarte w niniejszej pracy, o ile nie zaznaczono inaczej, pochodzą od autorów. W artykule zastosowano tradycyjny system znaków chińskich oraz transliterację Hanyu Pinyin do języka chińskiego i Między narodowy Alfabet Fonetyczny (IPA) do języka sui.

\section{Stan badań}

Języki tonalne stanowią przeszło połowę wszystkich języków świata (Yip 2002: 1), jednak wiele dotyczących ich szczegółowych zagadnień dopiero stosunkowo niedawno, bo od około połowy XX wieku, wzbudziło zainteresowanie językoznawców. Dopiero wówczas zaczęto szerzej analizować relacje pomiędzy tonami leksykalnymi a melodyką utworów wokalnych, czy rozumienie przekazu w warunkach ograniczonych możliwości artykulacji tonów, np. w trakcie śpiewu.

Zogniskowane na powyższych kwestiach badania języków azjatyckich, w zbiorze których mieści się sui, objęły dotychczas m.in. języki tajskie (List 1961, Lissoir \& Demolin 2015), wietnamskie (Kirby \& Ladd 2016), tybeto-birmańskie (Bright 1957) oraz chińskie (Chao 1956, Mark \& Li 1966, Yung 1983, Chan 1987, Wong \& Diehl 2002, Wee 2007, Schellenberg 2012). Poza nielicznymi wyjątkami (Bright 1957: 28), autorzy poszczególnych publikacji stwierdzają częściową lub kompletną zależność łączącą kontury sekwencji tonalnych z liniami melodycznymi utworów. Stopień owej zależności może być podyktowany specyfiką analizowanych gatunków, np. pieśni khap Tai Dam z północnego Laosu, oparte na stosunkowo skonwencjonalizowanych strukturach, wykazują relatywną tolerancyjność w realizacji tonów (Lissoir \& Demolin 2015: 4), podczas gdy improwizowana melodycznie opera kantońska oddaje je dość precyzyjnie

1 韋述啟 Wéi Shùq I - doktorant Instytutu Języ koznawstwa (語言研究所 Yǔyán Yánjiūusuǒ) Shanghai Normal University (上海師範大學 Shànghăi Shīfàn Dàxué) i wy kładowca języ ka sui na Guizhou Minzu University (貴州民族大學 Guìzhōu Mínzú Dàxué).

2 Kompozytor, muzykolog, skrzypek i pianista. Absolwent kompozycji Akademii Muzycznej im. Ignacego Jana Paderewskiego w Poznaniu w klasie dr hab. Moniki Kędziory oraz muzykologii na Uniwersytecie Adama Mickiewicza. 
(Yung 1983: 36-37). Luźniejsze przywiązanie do właściwości tonalnych daje się zaobserwować we współczesnych formach muzyki popularnej, których autorzy zwracają mniejszą uwagę na przekazywanie określonych treści (Lau 2010:2).

\section{Kultura ijęzykludu Sui}

Południowo-zachodnia część Chin była jedną z tych, które najdłużej opierały się centralnemu ośrodkowi władzy. Jeszcze w pierwszej połowie XX wieku, a nawet tuż po utworzeniu Chińskiej Republiki Ludowej, niektóre obszary tylko formalnie podlegały państwowej administracji, a życie w nich toczyło się podług miejscowych porządków. O wyjątkowości regionu w dużej mierze decydowało górskie, niesprzyjające wzajemnym kontaktom ukształtowanie terenu, oraz, przede wszystkim, zróżnicowanie zamieszkujących go społeczności. Systematyczne próby sklasyfikowania poszczególnych ludów, zapoczątkowane w latach 50. ubiegłego stulecia, zaowocowały oficjalnym uznaniem przez komunistyczny rząd szeregu mniejszości etnicznych. Podobne wyróżnienie spotkało m.in. dość nieliczną społeczność Sui. Jej członkowie, których populacja sięga obecnie 400 tys. (Pan \& Wei 2004: 1), w zdecydowanej większości zamieszkują południowo-wschodnie partie prowincji Guizhou 3, w szczególności Autonomiczny Powiat Sui Sandu4.

Wspomniany region, w którym Sui żyją po sąsiedzku z Hanami, Miao, Dong, Yao, Zhuang5 oraz reprezentantami innych grup etnicznych, nie jest miejscem ich pierwotnego pochodzenia. W tym stwierdzeniu zawiera się niemal wszystko, co w kontekście dawniejszej historii ludu nie budzi sporów badaczy. Część bowiem postrzega Sui jako potomków jednego z plemion Baiyue ${ }^{6}$ (por. Zeng 2004: 37), a inni, szczególnie reprezentanci samych zainteresowanych, dopatrują się korzeni grupy nawet w czasach i kręgu kulturowym dynastii Shang (商 Shāng, 1600-1046r. p.n.e.) (por. Pan \& Wei 2004: 11). Bez względu na faktyczny przebieg procesów dziejowych starożytności, Sui oraz pozostałe przywołane ludy łączą silne wpływy cywilizacji Równiny Centralnej 7 . Po osiedleniu się w rejonie obecnej prowincji Guizhou i jej przyległościach, co według niektórych źródeł miało nastąpić nie później niż w okresie panowania dynastii Tang (唐 Táng, 618-907) (por. Pan 2009: 95), tworzone przez Sui patriarchalne,

\footnotetext{
3貴州 Guìzhōu - prowincja w południowo-zachodniej części Chińskiej Republiki Ludowej ze stolicą w mieście Guiy ang (貴陽 Guìyáng).

4三都水族自治縣 Sāndōu Shu ̌zú Zìzhìxiàn - powiat w południowo-wschodniej części prowincji Guizhou. Z racji posiadanego statusu „powiatu autonomic znego”, zamieszkujący go Sui są liczniej reprezentowani $\mathrm{w}$ lokalnych władzach, a realizowane $\mathrm{w}$ szkołach programy kształcenia obejmująlekcje języka sui.

5漢 Hàn, 苗 Miáo, 侗 Dòng, 瑤 Yáo, 壯 Zhuàng.

6百越 Băiyuè - zbiorcze określenie dla częściowo zsinizowanych lub wolnych od chińskich wpływów kulturowych ludów, które na przełomie I tys. p.n.e. i I tys. n.e. zamieszkiwały rozległe tereny od Rzeki Długiej (Jangcy) aż do północnej części dzisiejszego Wietnamu. 7 中原 Zhōngyuán - nazwa obszaru środkowego i dolnego biegu Rzeki Żółtej, tradycyjnie postrzeganegojako miejsce narodzin cywilizacji chińskiej.
} 
klanowe społeczeństwo nie tylko przyswajało językowe zapożyczenia z chińskiego, ale również astronomiczne, astrologiczne i filozoficzne koncepcje. Te służyły jednak jako ramy dla rdzennych zwyczajów, w tym do dziś popularnych szamanisty cznych praktyk czy tradycyjnych świąt.

O wciąż silnej żywotności lokalnej kultury świadczy choćby status języka sui, którego na co dzień używa przeszło połowa członków społeczności (Grimes 2003: 210). Przyporządkowana do gałęzi kam-sui rodziny taj-kadajskiej mowa dominuje na terenach rolniczych, w piętrzących się na górskich zboczach lub rozlanych po dolinach wsiach. W większych ośrodkach bardziej praktycznymi okazują się zwykle południowo-zachodnie dialekty mandaryńskie. Podobnie do pozostałych języków gałęzi, sui cechuje się analitycznością, izolacyjnością oraz tonalnością. Szczególnie bogaty zasób dźwięków wyróżnia dialekt sandong (三洞 Sāndòng), jeden $\mathrm{z}$ trzech wspominanych porzez większość opracowań (por. Zeng 2004: 42, Zhang 1980: 75). Pozostałe dwa, tj. pandong (潘洞 Pāndòng) i yang'an (陽安 Yáng'ān), drugorzędne pod względem obszaru występowania i liczby użytkowników, cechuje mniejsza liczba spółgłosek. Dialekt sandong posiada ich aż 42, co w połączeniu z labializowanymi i palatalizowanymi zbitkami daje 71 możliwych nagłosów. Jedynie sześć spółgłosek, zwarte [p, t, k] oraz nosowe [m, n, y], może pełnić rolę kody. Dyftongi, budowane na bazie siedmiu podstawowych samogłosek, [i, e, ə, a, u, o, ר], pojawiają się tylko w sylabach otwartych, które wraz z sylabami zamkniętymi spółgłoskami nosowymi, są artykułowane na pierwszych sześciu z ośmiu dostępnych tonów. Ton siódmy i ósmy występują w sylabach zakończonych spółgłoskami zwartymi (cf. tab. 1, s. 27). W słownictwie dominują formy monosylabiczne, przypadki złożeń dotyczą głównie współczesnych zapoży czeń z języka chińskiego (Burkiewicz 2015: 64-68).

\begin{tabular}{l|l|l|l|l|r|r|r}
1 & 2 & 3 & 4 & 5 & 6 & 7 & 8 \\
$\lambda$ & $\vee$ & $f$ & $y$ & 1 & 7 & 7 & $y$ \\
13 & 31 & 33 & 52 & 35 & 55 & 35 & 42
\end{tabular}

Tab. nr 1: Graficzne oraz numeryczne reprezentacje ośmiu tonów $w$ dialekcie sandong. Przebieg siódmego i ósmego tonu zależy od braku (góra) lub obecności samogłoski długiej (dót).

Język sui jest nośnikiem bogatej literatury oralnej, która według samych członków ludu stanowi jeden z najważniejszych elementów ich tożsamości kulturowej. Choć Sui posiadają własny, oparty na logogramach system pisma (cf. fot. 1, s. 28), to jego zastosowanie ogranicza się do praktyk szamańskich i wróżbiarskich, a ograniczony zasób znaków, w większości piktogramów, nie wystarcza do oddania bardziej złożonych treści. Wiedza o ważnych wydarzeniach $\mathrm{z}$ przeszłości czy zwyczajach 
tradycyjnie była przekazywana drogą ustną w postaci utworów literackich. Służyły one także promowaniu wartości moralnych czy nawiązywaniu i kształtowaniu relacji międzyludzkich. Nawet współcześnie, choć już w mniejszym stopniu, umiejętność wykonania odpowiednich dla danej sytuacji pieśni, przysłów lub maksym pozwala cieszyć się opinią osoby o wysokim poziomie kultury osobistej (Burkiewicz 2015:43).

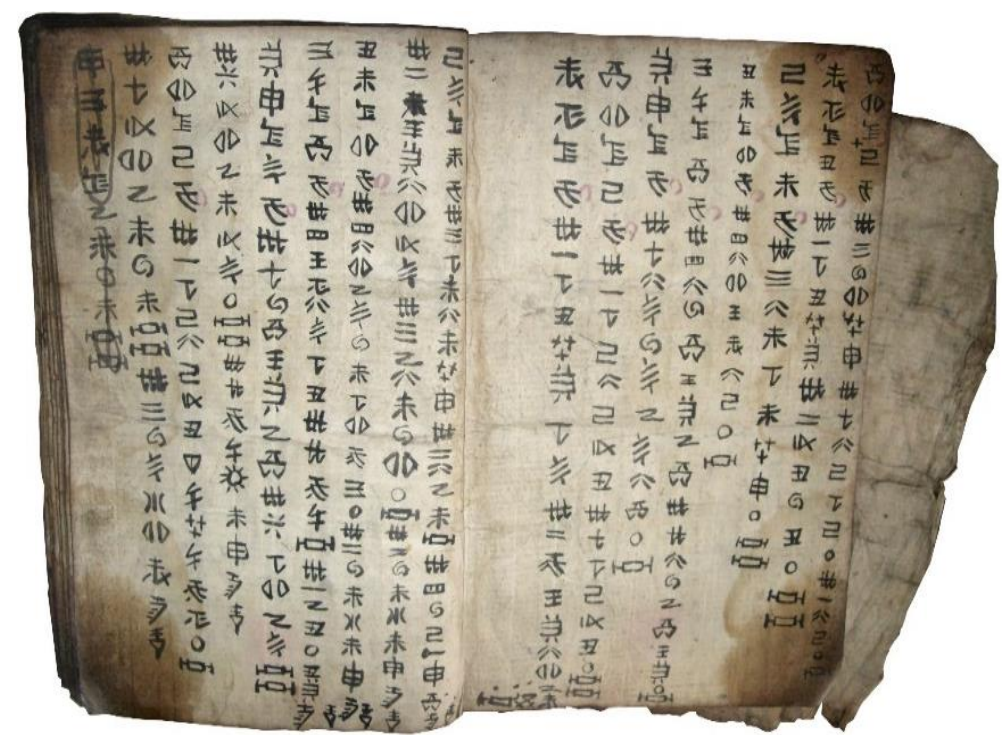

Fot. nr 1: Księga wróżbiarska sporządzona w piśmie sui.

\section{Pieśni i muzyka Sui}

Chiny to jedna z najstarszych kultur muzycznych świata, a jej źródła, m.in. na podstawie wykopalisk $\mathrm{w}$ prowincji Henan ${ }^{8}$ szacowane są na około osiem tysięcy lat p.n.e. Choć badania nad historią muzyki chińskiej są z reguły skoncentrowane na tradycji wywodzącej się z Równiny Centralnej oraz tzw. muzyce eleganckiej (雅樂 yăyuè) i dworskiej (宮殿音樂 gōngdiàn yīnyuè), Państwo Środka niewątpliwie może się poszczycić wyjątkowo bogatą i złożoną mozaiką odmiennych form muzycznych, zarówno w przypadku twórczości wokalnej, jak i instrumentalnej.

Zgodnie z klasyfikacją Shena, opartą na kryterium przynależności etnicznej, pieśni ludowe Sui przyporządkowuje się do grupy Yue-Pu (越洋 Yuè Pú), jednego $\mathrm{z}$ trzech systemów południowej muzyki chińskiej ${ }^{9}$, charakteryzującego się preferencją pentatoniki oraz częstego stosowania interwału kwarty w jej obrębie (2002: 485-486). Pieśni Sui nie zostały jeszcze poddane szczegółowym analizom muzykologicznym, brakuje również zgodności względem ich typologii. Badacze wyróżniają kilka podstawowych gatunków:

\footnotetext{
${ }^{8}$ W 1986 roku na stanowisku archeologicznym w Jiahu (賈湖) wydobyto kilka fletów kostnych, z których najlepiej zachowane mają siedem otworów palcowych. Podobne instrumenty, datowane na 5000 p.n.e. odkryto również w Hemudu (河姆渡) w prowincji Zhejiang i Meiy an (梅堰) w prowincji Jiangsu (Wu 2002:105).

9Pozostałe dwa sy stemy do Di-Qiang (氐后 Dī Qiāng) i Miao-Yao (苗瑤 Miáo Yáo).
} 
Hanna Kupś, Kamil Burkiewicz: Tonalność języka w pieśni na podstawie utworów biesiadnych ludu Sui

Pieśni narracyjne (古歌 $g u ̌ g e \bar{e},\left[\operatorname{cip}^{8} \mathrm{tsi}^{5}\right]$ ) - śpiewane zwykle przez osoby starsze przy wielu okazjach, w tym swatania i rozwiązywania sporów; ich treść stanowią przede wszystkim tradycyjne opowieści i legendy.

$>$ Pieśni górskie (山歌 shāngē, znane też np. jako „pojedyncze” 單歌 dānge,$\left.\left[\operatorname{cip}^{8} \mathrm{tsik}^{7}\right]\right)$ - wykonywane podczas świąt, wizyt w sąsiednich wioskach czy wędrówek po wzgórzach; dotyczą głównie miłości i romantycznych uniesień.

Pieśni biesiadne (酒歌 jǚge, znane też np. jako “podwójne” 雙歌 shuānggēe, [6ip ${ }^{8}$ tsau $\left.^{8}\right]$ ) - od pozostałych gatunków odróżnia je rozwinięcie $\mathrm{w}$ formie dialogu pomiędzy gospodarzem i podejmowanym gościem; śpiewane $\mathrm{w}$ czasie świąt i spotkań towarzyskich dla uwy datnienia serdecznych relacji ${ }^{10}$.

$>$ Piosenki dziecięce (兒歌 érgē, [6ip $\left.8 \mathrm{la}^{8} \mathrm{k}^{8} \mathrm{ti}^{3}\right]$ ) - kołysanki, wyliczanki i inne utwory o charakterze rozrywkowym lub dy daktycznym.

$>$ Pieśni dou (萖歌 dōuge, [6ip ${ }^{8}$ hon$\left.^{2}\right]$ ) - zakresem tematycznym nawiązują do pieśni narracyjnych i górskich, wyróżnia je jednak struktura kompozycyjna, łącząca część mówioną i melorecytowaną.

$>$ Pieśni o [Qon ${ }^{5} \mathrm{Ljok}^{8} \mathrm{to}^{2}$ ] (公六奪的歌 Gōng Liùduó de gē) utwory poświęcone legendarnemu twórcy pisma sui.

> Pieśni czterowersowe po siedem sylab (七言四句歌 qī yán sì jù gēe) - formy śpiewane w języku chińskim, popularne wśród społeczności Sui w rejonie Duyun ${ }^{11}$ (Pan \& Wei 2004: 436-467, Li \& Zhang 1998: 602604).

Bogatą tradycję muzyczną ludu Sui dopełnia twórczość instrumentalna. Wykonywanym pieśniom lub tańcom towarzyszą dźwięki wydobywane głównie z aerofonów, w tym lusheng (蘆笙) i mangtong (莽筒), oraz idiofonów, takich jak mugu (木鼓) i tonggu (銅鼓) (Li \&Zhang 1998: 604).

10Li \& Zhang uznają „pieśni biesiadne” i „pieśni podwójne” za tożsame, podczas gdy Pan \& Wei wskazują, że pierwsze sąjedy nie podtypem drugich.

11都匀 Dūyún - miasto prefekturalne w prowincji Guizhou, od południa graniczy z powiatem Sandou. 


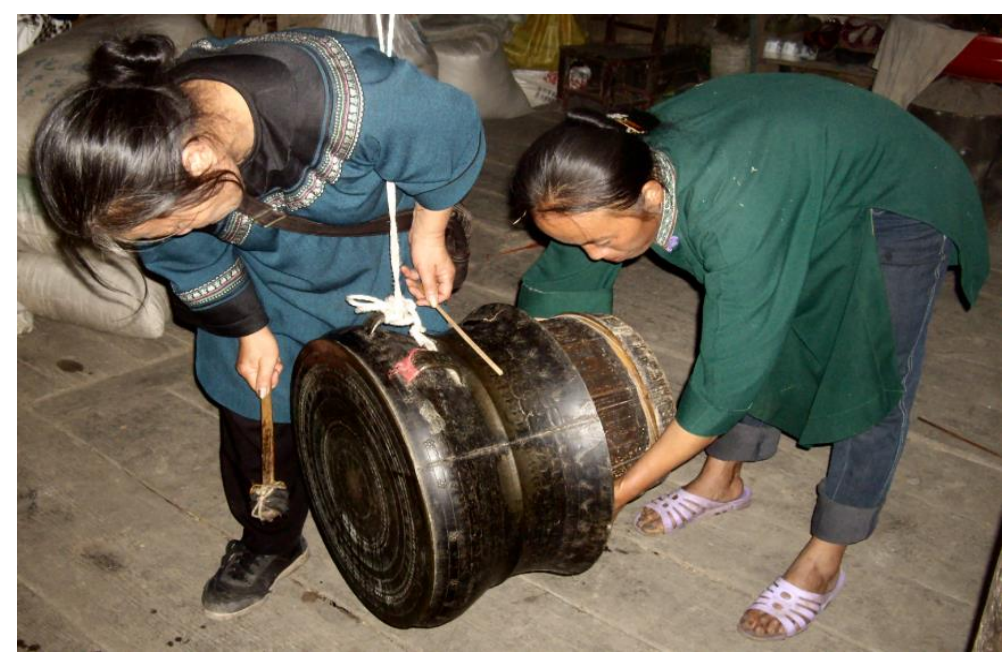

Fot.nr 2: Kobiety Sui grajace na tonggu.

\section{Metodologia}

Za materiał badawczy posłużyły cztery tradycyjne utwory ludu Sui, spośród których dwa odpowiadają charakterystyce pieśni górskich, a pozostałe można zakwalifikować jako kompozycje biesiadne. Przy braku jakichkolwiek informacji wydawniczych dot. przekazanych przez Muzeum Kultury Powiatu Sandu nagrań, jakość zawartych w nich wokali i instrumentariów pozwala jedynie domniemywać, że zostały wykonane przez profesjonalistów w warunkach studyjnych. Poszczególne utwory mają różną długość, przy czym szczegółowej analizie poddano wybrane fragmenty, opisane w poniższej tabeli i ujęte w formie załącznika. Inaczej niż w tradycji chińskiej, przebieg linii melodycznych oddano w postaci nut rozpisanych na pięciolinii, a nie notacji numerycznej. Towarzyszą im zapisane w IPA teksty pieśni.

\begin{tabular}{|c|c|c|}
\hline Tytuł (chiński i polski) & $\begin{array}{c}\text { Długość, wybrany } \\
\text { fragment, format pliku }\end{array}$ & $\begin{array}{c}\text { Gatunek, charakterystyka } \\
\text { fragmentu }\end{array}$ \\
\hline $\begin{array}{l}\text { 相思戀 Xiāngsīliàn } \\
\text { Miłosna tęsknota }\end{array}$ & $\begin{array}{l}02: 46,00: 00-02: 46, \\
\text { wav }\end{array}$ & $\begin{array}{l}\text { pieśń górska, partie } \\
\text { głosu żeńskiego, mę- } \\
\text { skiego, mieszanego } \\
\text { i chóru żeńskiego, opo- } \\
\text { wieść o tęsknocie po- } \\
\text { między zakochanymi }\end{array}$ \\
\hline $\begin{array}{l}\text { 金秋端節 Jinqiū Duānj̈ié } \\
\text { Święto Duan w zlota jesien }\end{array}$ & $\begin{array}{l}\text { o4:38, 01:09-02:53, } \\
\text { mp3 }\end{array}$ & $\begin{array}{l}\text { pieśń górska, partie } \\
\text { chóru żeńskiego, mę- } \\
\text { skiego i mieszanego, } \\
\text { pochwała pracy z okazji } \\
\text { zakończonych zbiorów }\end{array}$ \\
\hline $\begin{array}{l}\text { 雙歌 Shuānggēe } \\
\text { Pieśń podwójna }\end{array}$ & $\begin{array}{l}\text { 09:07, 00:36-01:52, } \\
\text { wav }\end{array}$ & $\begin{array}{l}\text { pieśń biesiadna, partie } \\
\text { głosu żeńskiego i mę- } \\
\text { skiego, pieśń w formie }\end{array}$ \\
\hline
\end{tabular}


Hanna Kupś, Kamil Burkiewicz: Tonalność języka w pieśni na podstawie utworów biesiadnych ludu Sui

\begin{tabular}{l|l|l} 
& $\begin{array}{l}\text { dialogu pomiędzy zako- } \\
\text { chanymi } \\
\text { 敬酒歌 Jìngjún biesiadna, partia } \\
\text { Pieśn toastowa }\end{array}$ & $\begin{array}{l}\text { oo:24, o0:00-00:24, } \\
\text { głosu żeńskiego i mie- } \\
\text { wavanego, uroczyste } \\
\text { przywitanie gościa }\end{array}$
\end{tabular}

Tab. nr 2: Opis pieśni wykorzystanych w badaniu.

Zgodnie z teorią Ladda, reprezentacja tonów w śpiewie sprowadza się do dwóch typów efektów, tj. fonetycznych i strukturalnych. Do pierwszych należą zabiegi służące rozróżnieniom fonologicznym w sytuacjach, gdy wysokości dźwięków są ograniczane przebiegiem melodii. W tej kategorii mieszczą się m.in. wartości alofoniczne czy długości samogłosek. Stosunkowo lepiej zbadane efekty strukturalne polegają na dopasowaniu muzycznej melodii i konturów tonów, kosztem mniejszej swobody kompozycyjnej (2013: 1-3). Specyfika zróżnicowanego materiału nie pozwoliła jednak na powtórzenie analizy zaproponowanej przez Chan, której celem było rozstrzygnięcie kwestii, czy twórcy pieśni kierowali się tonami leksykalnymi przy doborze słów (1987: 29) 12. Wybór czterech utworów, reprezentujących pieśni górskie i biesiadne, umożliwił za to zbadanie korespondencji sekwencji tonalnych z liniami melodycznymi w obrębie danej formy, a także potencjalnego wpływu gatunku muzycznego na reprezentację tonów leksykalnych.

Przedstawiona poniżej analiza koncentruje się na sprawdzeniu strukturalnej relacji pomiędzy melodią a tonami leksykalnymi w ujęciu zaproponowanym przez Wonga i Diehla. W swoim artykule stwierdzili, że opadaniu lub podnoszeniu się melodii z jednej nuty na następną powinna towarzyszyć adekwatna sekwencja tonów przyporządkowanych im par sylab. Podobnie jak Chan (1987: 27), w przeprowadzonych badaniach wzięli pod uwagę końcowe wysokości konturów tonów, dzieląc je na trzy grupy: wysokie, średnie i niskie, które następnie posłużyły ocenie stopnia współzależności z przebiegiem melodii (Wong \& Diehl 2002: 205). Takie rozwiązanie wybrali również autorzy niniejszego opracowania względem języka sui. W analogicznych grupach zestawili odpowiednio tony 5, 6 i 7, 1 i 3, oraz 2, 4 i 8 (cf. tab. 1, s. 27) ${ }^{13}$. Następnie w każdym z wyżej określonych fragmentów pieśni porównali wznoszenie, opadanie lub równy poziom sekwencji tonalnych kolejnych, nieprzedzielonych pauzami par sylab z odpowiadającymi im nutami. Obok sylab przypisanych pojedynczym dźwiękom, badanie objęło również przypadki melizmatów, czyli figur

12Analiza utworów w języku kantońskim wykazała zastosowanie określonych sekwencji tonalnych przy podobnych melodiach, co sugeruje, że tony leksykalne były brane pod uwagę w trakcie tworzenia tekstów pieśni.

13W niniejszym opracowaniu zastosowano podział tonów podobny do klasy fikacji Wonga i Diehla (2002: 204). W ramach pięciostopniowej skali przebiegu konturów tonów, te z nich, które kończą się na piątym, najwyższym stopniu, zostały umieszczone w grupie wy sokich, zwieńczone na trzecim stopniu (brak przypadków finalizowanych na czwartym) w grupie średnich, natomiast tony osiągające drugi i pierwszy stopień znalazły się w grupie niskich. 
melodycznych śpiewanych na jednej sylabie. Zależnie od pozycji melizmatu, tj. w pierwszym lub drugim elemencie danej pary, sprawdzono jego końcową lub początkową nutę. Wspomniane figury, do których autorzy zaliczyli również ozdobniki, zostały poddane dodatkowej analizie (cf. tab. 5, s. 33).

Kryteria oceny zgodności tonów leksykalnych z melodią oparto na następujących zależnościach: rosnącej sekwencji tonów powinno towarzyszyć podniesienie wysokości dźwięków, sekwencji opadającej obniżenie, a przy tonach równych zachowanie jednolitego poziomu. Wzorem Wonga i Diehla (2002: 205), wznoszenie melodii przy tonach o podobnej wartości rozpatrzono jako osobny przypadek, którego procentowy udział okazał się być znaczący (cf. tab. 6, s. 34).

\section{Analiza i rezultaty}

Najdłuższy utwór korpusu, Miłosna tęsknota, zawiera 180 sylab, a najkrótszy, Pieśń toastowa, tylko 43. We wszystkich pieśniach najliczniejszą grupę stanowią sylaby w tonach średnich, obejmujące od $45 \%$ do $62 \%$ ogółu. Poza drugim ze wspomnianych utworów, ze znikomą liczbą tonów niskich (16\%), w pozostałych przy padkach do najrzadszych należą tony wysokie (od $11 \%$ do 17\%). We wszystkich pieśniach zaobserwowano obecność zarówno sylab śpiewanych na pojedynczych dźwiękach, jak i melizmatów, ze znaczną przewagą tych pierwszych (cf. tab. 3). Sylaby odpowiadające jednej nucie w większości reprezentują grupę tonów średnich (od 50\% do 70\%), natomiast melizmaty grupy tonów średnich lub niskich (odpowiednio 50\% i 54\% oraz w dwóch przypadkach 54\%). Wyraźną regularność stwierdzono także w przyporządkowaniu określonych nut do sylab na tonach wysokich, np. w Pieśni toastowej przy 8 z 9 podobnych tonów występuje dźwięk A (440Hz), co częściowo wpisuje się w obserwacje poczynione przez Yunga (1983: 37-38). Równie ścisłych relacji, obecnych w operze kantońskiej, nie stwierdzono jednak względem pozostałych tonów w badanych pieśniach sui.

\begin{tabular}{|c|c|c|c|c|c|}
\hline & Dźwięki Tony & wysokie & średnie & niskie & razem \\
\hline \multirow{2}{*}{$\begin{array}{l}\text { Miłosna } \\
\text { tęsknota }\end{array}$} & pojedyncze & $15 / 75 \%$ & $98 / 88 \%$ & $28 / 57 \%$ & $141 / 78 \%$ \\
\hline & melizmaty & $5 / 25 \%$ & $13 / 12 \%$ & $21 / 43 \%$ & $39 / 22 \%$ \\
\hline \multirow{2}{*}{$\begin{array}{l}\text { Święto Duan } \\
\text { w złota jesień }\end{array}$} & pojedyncze & $15 / 88 \%$ & $41 / 75 \%$ & $22 / 69 \%$ & $78 / 75 \%$ \\
\hline & melizmaty & $2 / 12 \%$ & $14 / 25 \%$ & $10 / 31 \%$ & $26 / 25 \%$ \\
\hline \multirow{2}{*}{$\begin{array}{c}\text { Pieśńn } \\
\text { podwójna }\end{array}$} & pojedyncze & $20 / 80 \%$ & $55 / 81 \%$ & $36 / 63 \%$ & $111 / 74 \%$ \\
\hline & melizmaty & $5 / 20 \%$ & $13 / 19 \%$ & $21 / 37 \%$ & $39 / 26 \%$ \\
\hline \multirow{2}{*}{$\begin{array}{c}\text { Pieśń } \\
\text { toastowa }\end{array}$} & pojedyncze & $9 / 75 \%$ & $19 / 79 \%$ & $5 / 71 \%$ & $33 / 77 \%$ \\
\hline & melizmaty & $3 / 25 \%$ & $5 / 21 \%$ & $2 / 29 \%$ & $10 / 23 \%$ \\
\hline
\end{tabular}

Tab. $n r$ 3: Porównanie liczb oraz wskaźników procentowych sylab śpiewanych na dźwiękach pojedynczych i melizmatach $w$ poszczególnych grupach tonalnych.

Ogół badanych utworów łączy zdecydowana dominacja łagodnych przejść tonalnych. Wśród stosunkowo nielicznych bezpośrednich przeskoków z tonu wysokiego na niski lub niskiego na wysoki, te drugie 
Hanna Kupś, Kamil Burkiewicz: Tonalność języka w pieśni na podstawie utworów biesiadnych ludu Sui

wyróżniają się wysokim współczynnikiem zgodności z melodią (cf. tab. 4).

\begin{tabular}{|c|c|c|}
\cline { 2 - 3 } \multicolumn{1}{c|}{} & \multicolumn{2}{c|}{ Przeskok z tonu } \\
\cline { 2 - 3 } \multicolumn{1}{c|}{} & wysokiego na niski & niskiego na wysoki \\
\hline Miłosna tęsknota & $5 / 40 \%$ & $4 / 100 \%$ \\
\hline Święto Duan w złota jesień & $4 / 0 \%$ & $5 / 80 \%$ \\
\hline Pieśń podwójna & $9 / 78 \%$ & $8 / 75 \%$ \\
\hline Pieśń toastowa & $2 / 0 \%$ & $1 / 100 \%$ \\
\hline
\end{tabular}

Tab. nr 4: Liczba i procentowa zgodność przeskoków tonalnych z melodia.

Celem osobnego badania melizmatów było sprawdzenie, czy brzmienie sylab na tonach ekstremalnych, tj. wysokich i niskich, zostało podkreślone utrzymaniem melodii na tym samym poziomie oraz odpowiednio jej wznoszeniem lub opadaniem. Rezultat porównania wykazał szerokie zastosowanie takiego rozwiązania względem tonów niskich. Tylko utwory górskie wyróżniły się wysoką zgodnością również w przypadku tonów wysokich. Nie stwierdzono zauważalnej korelacji tonów średnich z płaskim przebiegiem melodii (cf. tab. 5).

\begin{tabular}{|c|c|c|c|c|}
\cline { 2 - 5 } \multicolumn{1}{c|}{} & \multicolumn{4}{c|}{ Przypadające na melizmaty tony } \\
\cline { 2 - 5 } \multicolumn{1}{c|}{} & wysokie & średnie & niskie & razem \\
\hline Miłosna tęsknota & $5 / 80 \%$ & $13 / 38 \%$ & $21 / 100 \%$ & $39 / 73 \%$ \\
\hline Święto Duan w złota jesień & $2 / 100 \%$ & $14 / 14 \%$ & $10 / 80 \%$ & $26 / 65 \%$ \\
\hline Pieśń podwójna & $5 / 40 \%$ & $11 / 9 \%$ & $21 / 95 \%$ & $37 / 48 \%$ \\
\hline Pieśń toastowa & $3 / 33 \%$ & $5 / 0 \%$ & $2 / 100 \%$ & $10 / 44 \%$ \\
\hline
\end{tabular}

Tab. $n r$ 5: Liczba sylab $w$ określonych grupach tonalnych śpiewanych na melizmatach oraz ich procentowa zgodność z melodia.

Zasadnicza część badania, czyli próba określenia stopnia przełożenia relacji tonów sąsiednich sylab na linię melodyczną, dowiodła istnienia wysokiej zgodności tylko w określonych typach par sylab. Najwyższy, bo ponad 90\% współczynnik, zaobserwowano w zestawieniach tonów niskich z wysokimi oraz wysokich ze średnimi. Nieznacznie niższą zgodność cechują ciągi sylab średnich i wysokich. W pozostałych przypadkach, obejmujących sekwencje wznoszące i opadające, korelacja okazała się występować znacznie rzadziej, oscylując na granicy istotności względem par sylab niskich i średnich lub mieszcząc się poniżej tego progu. Badanie nie wykazało istnienia relacji pomiędzy wysokością dźwięków a układami tonów na równym poziomie. Dopiero uwzględnienie melodii wznoszącej, za przykładem Wonga i Diehla (2002: 205), pozwoliło na uzyskanie znacząco wyższych wyników. Średnia zgodność dla tonów wysokich we wszystkich utworach wzrosła do 63\% (pierwotnie 25\%), dla tonów średnich 55\% (18\%), dla tonów niskich 47\% (30\%). 


\begin{tabular}{|r|r|c|c|c|c|}
\cline { 3 - 6 } \multicolumn{2}{c|}{} & tęsknota & w ztota jesien & podwójna & toastowa \\
\hline & wysoki-wysoki & $2 / 0 \% / 50 \%$ & $1 / 100 \% / 100 \%$ & $3 / 0 \% / 0 \%$ & $1 / 0 \% / 100 \%$ \\
\cline { 2 - 6 } & wy soki-średni & $12 / 100 \%$ & $10 / 80 \%$ & $13 / 100 \%$ & $8 / 88 \%$ \\
\cline { 2 - 6 } & wysoki-niski & $6 / 50 \%$ & $4 / 0 \%$ & $9 / 78 \%$ & $3 / 33 \%$ \\
\cline { 2 - 6 } & średni-wysoki & $11 / 64 \%$ & $10 / 90 \%$ & $12 / 75 \%$ & $9 / 89 \%$ \\
\cline { 2 - 6 } & średni-średni & $76 / 11 \% / 47 \%$ & $25 / 20 \% / 56 \%$ & $33 / 18 \% / 60 \%$ & $9 / 22 \% / 55 \%$ \\
\cline { 2 - 6 } & średni-niski & $22 / 23 \%$ & $12 / 33 \%$ & $21 / 14 \%$ & $5 / 20 \%$ \\
\cline { 2 - 6 } & niski-wysoki & $4 / 100 \%$ & $6 / 83 \%$ & $8 / 88 \%$ & $1 / 100 \%$ \\
\cline { 2 - 6 } & niski-średni & $17 / 94 \%$ & $11 / 36 \%$ & $20 / 60 \%$ & $5 / 20 \%$ \\
\hline & niski-niski & $23 / 26 \% / 43 \%$ & $9 / 44 \% / 66 \%$ & $25 / 20 \% / 32 \%$ & $0 /-/-$ \\
\cline { 2 - 6 } & razem & $173 / 35 \% / 53 \%$ & $88 / 45 \% / 58 \%$ & $144 / 43 \% / 55 \%$ & $41 / 51 \% / 61 \%$ \\
\hline
\end{tabular}

Tab. $n$ r 6: Liczba i procentowa zgodność par sylab w określonych grupach tonalnych z przebiegiem linii melodycznej (w parach tonów na jednym poziomie także procentowa zgodność uwzględniająca melodię równą $i$ wznosząca).

\section{Wnioski}

Poza spostrzeżeniami dokonanymi odnośnie melizmatów na tonach wysokich (cf. s. 33), analiza materiału nie wykazała wpływu form gatunkowych, tj. pieśni górskiej i biesiadnej, na poziom zgodności sekwencji tonów leksykalnych $\mathrm{z}$ liniami melodycznymi. Pozwala to przypuszczać, że styl wykonywanego utworu ma tylko niewielkie przełożenie na stopień precyzji muzycznego odzwierciedlenia charakterystyki fonologicznej tekstu. Brak zależności może jednak wynikać z ograniczonego korpusu pieśni i wymaga dalszego, poszerzonego badania z uwzględnieniem pozostałych gatunków.

Wszystkie utwory łączą podobne proporcje sylab śpiewanych na pojedynczych nutach względem melizmatów (około 3:1). Znaczna przewaga tych pierwszych świadczy o większej istotności powiązania tonów leksykalnych z określoną wysokością dźwięków niż oddania ich konturów w postaci rozbudowanych figur melodycznych.

Inaczej niż np. w utworach w języku kantońskim, w których stwierdzono wyraźną korelację muzyki i tonów śpiewanego tekstu, pieśni sui nie wykazują analogicznych zbieżności. Wyjątek stanowią sekwencje wznoszące, oparte na zestawieniach tonu niskiego z wysokim, średniego z wysokim oraz niskiego ze średnim, co dodatkowo sugeruje szczególną funkcję tonu wysokiego. Potwierdza ją również tendencja do przypisywania mu określonej nuty (cf. s. 32). Analiza melizmatów zaprzecza jednak całkowitej dowolności w melodyce sylab na tonach niskich, która w wielu przypadkach zmierzała ku niższym rejestrom. Pary sylab utrzymujących ten sam poziom tonów, choć stosunk owo liczne, wykazały tylko nieznaczną zgodność z liniami melodycznymi, być może poświęconą na rzecz uzyskania większej różnorodności muzycznej utworów. Zastosowane w nich środki kompozycyjne nie służą więc zwiększeniu stopnia zrozumiałości słów, tym samym dokładność oddania tonów leksykalnych 
Hanna Kupś, Kamil Burkiewicz: Tonalność języka w pieśni na podstawie utworów biesiadnych ludu Sui

w melodii może mieć mniejsze znaczenie dla odbiorców przekazu.

W dalszym toku badań autorzy planują rozszerzyć je o analizę wyszczególnionych przez Ladda efektów fonetycznych (Ladd 2013: 2). Pogłębiony w ten sposób obraz realizacji tonów leksykalnych w pieśniach sui porównają z sytuacją w innych językach gałęzi kam-sui.

\section{Bibliografia}

Burkiewicz, Kamil 2015. The Script and Language of the Sui in Southern China: Description, Dictionary, Relations with Chinese Language and Culture. Dysertacja doktorska napisana w Katedrze Orientalistyki Uniwersytetu im. Adama Mickiewicza w Poznaniu.

Bright, William 1957. „Singing in Lushai”. Indian Linguistics, 17. Pp. 24-28.

Chan, Marjorie K. M. 1987. „Tone and melody in Cantonese”. Proceedings of the Thirteenth Annual Meeting of the Berkeley Linguistics Society. Pp. 26-37.

Chao, Yuan Ren 1956. „Tone, intonation, singsong, chanting, recitative, tonal composition and atonal composition in Chinese". W: M. Halle [\&] H. G. Lund [\&] H. McLean [\&] C. H. Van Schooneveld (ed.). For Roman Jacobson: Essays on the occasion of his sixtieth birthday, 11th October 1956. The Hague: Monton \& Co. Pp. 52-59.

Grimes, Barbara 2003. „Language List”. W: Frawley, William (ed.). International Encyclopedia of Linguistics (second edition, vol. 4). Oxford: Oxford University Press.

Kirby, James [\&] D. Robert Ladd 2016. „Tone-melody correspondence in Vietnamese popular song”. Tonal Aspects of Languages 24-27 May 2016. Pp. 48-51.

Ladd, D. R. 2013. Singing in tone languages: Phonetic and structural effects. Text of talk presented at the $27^{\text {th }}$ annual meeting of the Phonetic Society of Japan, Kanazawa, September.

Lau, Elaine 2010. „Tone-melody Relationship in Cantonese”. Working Papers in Linguistics: University of Hawai'i at Manoa, 41 (3). Pp. 1-12.

Li Jichang 李繼昌 [\&] Zhang Zhongxiao 張中笑 1998. „Shuizu Yinyue” 水族音樂 [muzyka Sui]. W: Zhongguo Dabaike Quanshu Zongbianji Weiyuanhui 《Yinyue, Wudao》Bianji Weiyuanhui (ed.) 中國大百科全書總編輯委員會《音 樂，舞蹈》編輯委員會 ( 編 ). Zhongguo Dabaike Quanshu: Yinyue, Wudao [wielka Encyklopedia Chińska: Muzyka, Taniec]. Beijing 北京: Zhongguo Dabaike Quanshu Chubanshe 中國大百科全書出版社. Pp. 603-604.

Lissoir, Marie-Pierre [\&] Didier Demolin 2015. „The relationships between speech tone and melody in the khap singing of Tai Dam in Laos". Proceedings of the $18^{\text {th }}$ International Congress of Phonetics Sciences. Glasgow: University of Glasgow. Paper number 919, pp. 1-4.

List, George 1961. „Speech melody and song melody in central Thailand”. Ethnomusicology, 5 (1). Pp. 16-32.

Mark, Lindy L. [\&] Fang Kuei Li 1966. „Tone and Melody in Wu-Ming Folk Song”. Artibus Asiae. Supplementum, Vol. 23, Essays Offered to G. H. Luce by His Collegues and Friends in Honour of His Seventy-Fifth Birthday. Volume 1: Papers on Asian History, Religion, Languages, Literature, Music Folklore, and Anthropology. Pp. 167-186. 
Pan Chaolin 潘朝霖 [\&] Wei Zonglin 韋宗林 2004. Zhongguo Shuizu Wenhua Yanjiu 中國水族文化研究 [studia nad kulturą grupy etnicznej Sui w Chinach]. Guiyang 貴陽: Guizhou Minzu Chubanshe 貴州人民出版社.

Pan Yizhi 潘－志 2009. Pan Yizhi Wenji 潘一志文集 [zbiór pism Pan Yizhi]. Chengdu 成都: Sichuan Chuban Jituan 四川出版劇團.

Schellenberg, Murray Henry 2012. „Does Language Determine Music in Tone Languages". Ethnomusicology, Vol 56, No. 2 (Spring/Summer 2012). Pp 266-278.

Shen Qia 2002. „National Minorities in China's South and Southwest: Ethnic Groups and Musical Styles”. W: Robert C. Provine [\&] Yosihiko Tokumaru [\&] J. Lawrence Witzleben (ed.). The Garland Encyclopedia of World Music, Vol. 7, East Asia: China, Japan, and Korea. New York and London: Routledge.

Wee, L. H. 2007. „Unravelling the relation between Mandarin tones and musical melody”. Journal of Chinese Linguistics, 35 (1). Pp. 128-143.

Wong, P. C. M. [\&] R. L. Diehl 2002. „How Can the Lyrics of a Song in a Tone Language Be Understood?”. Psychology of Music, Vol. 30 (2). Pp. 202-209.

Wu Ben 2002. „Archeology and History of Musical Instruments in China.” W: Robert C. Provine [\&] Yosihiko Tokumaru [\&] J. Lawrence Witzleben (ed.). The Garland Encyclopedia of World Music, Vol. 7, East Asia: China, Japan, and Korea. New York and London: Routledge.

Yip, Moira 2002. Tone. Cambridge: Cambridge University Press.

Yung, Bell 1983. „Creative process in Cantonese opera I: The role of linguistic tones". Ethnomusicology, 27. Pp. 29-47.

Zeng Xiaoyu 曾曉渝 2004. Hanyu Shuiyu Guanxi Lun 漢語水語關係論 [dyskusja nad związkami pomiędzy językiem chińskim i sui]. Beijing 北京: Shangwu Yinshuguan 商務印書館.

Zhang Junru 張均如 (ed.) 1980. Shuiyu Jianzhi 水語簡志 (krótki opis języka sui). Beijing 北京: Minzu Chubanshe 民族出版社.

\section{Załączniki}

Miłosna tęsknota 相思戀 
Hanna Kupś, Kamil Burkiewicz: Tonalność języka w pieśni na podstawie utworów biesiadnych ludu Sui
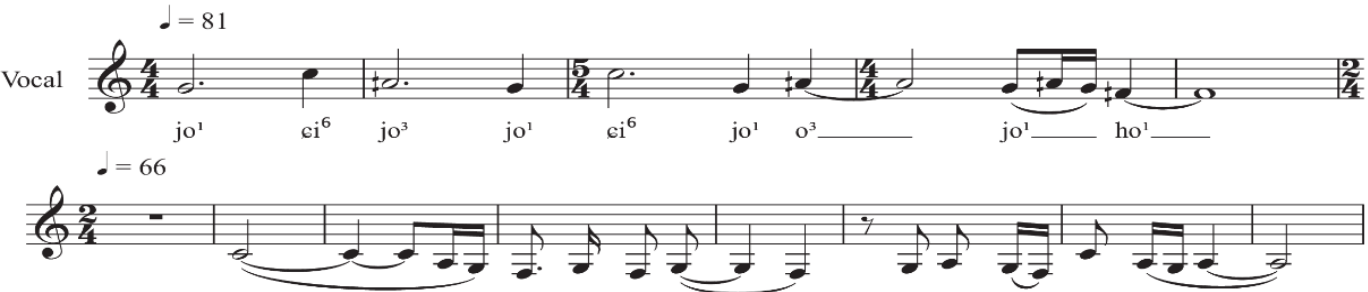

$\operatorname{van}^{1} \mathrm{pa}^{1} \mathrm{i}^{\mathrm{q}} \mathrm{qon} \mathrm{ai}^{2}$

tsum $^{2}$ lon $^{2}$ ?nam ${ }^{3} \mathrm{ni}^{3}$

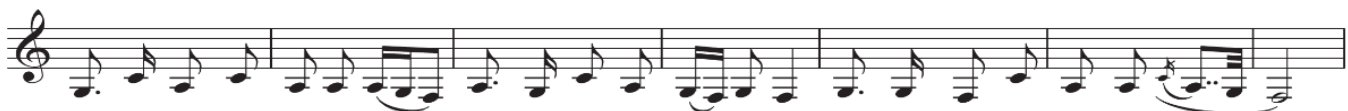

tən $^{6} \mathrm{hui}^{6} \mathrm{hi}^{3}$ Pnam $^{3} \mathrm{ngi}^{3} \mathrm{fi}^{3} \mathrm{fju}^{2}$ - fja: $\mathrm{u}^{3} \mathrm{tui}^{4} \mathrm{au}^{4} \mathrm{log}^{2} \mathrm{ju}^{2}-\mathrm{qo}^{3} \mathrm{sa}^{1} \mathrm{cau}^{3}$ Pdai $^{3}$ Pma $^{1}$ yo $\mathrm{tja}^{3} \mathrm{n}^{3} \mathrm{ha}^{2} \mathrm{pjau}^{2}$
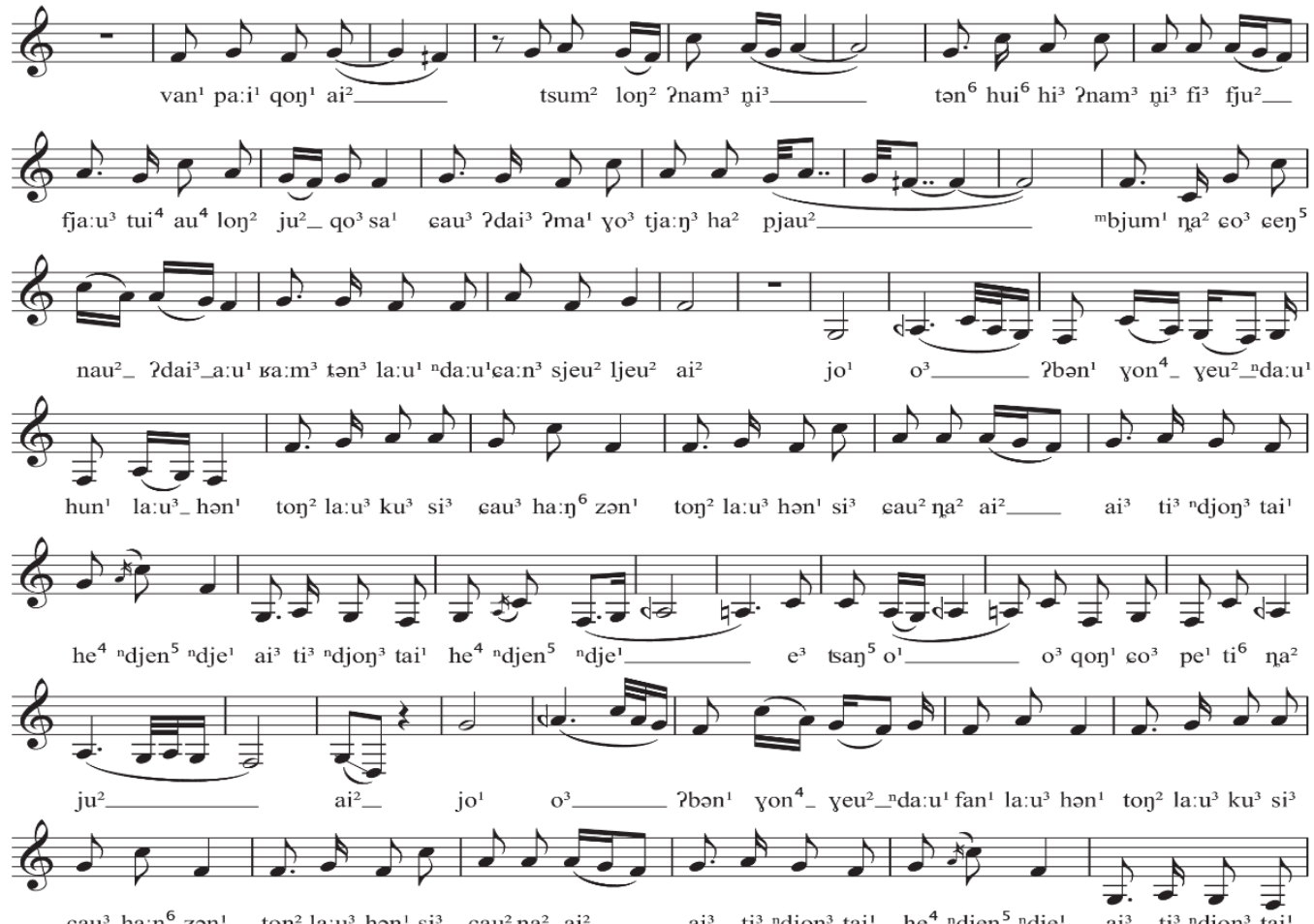

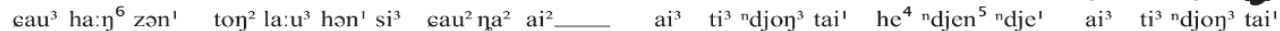

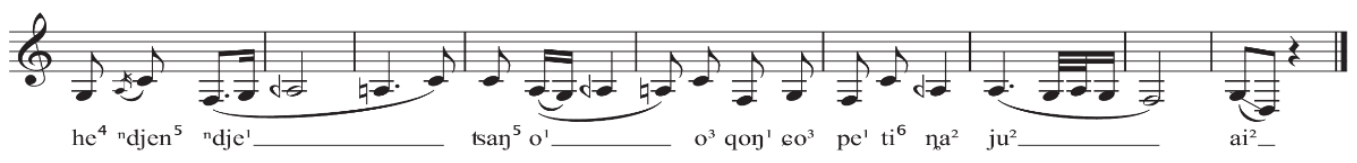

JFW $\mathbb{C}$ 
INVESTIGATIONES LINGUISTICAE VOL. XXXVI, 2017

(C) INSTITUTE OF LINGUISTICS - ADAM MICKIEWICZ UNIVERSITY

AL. NIEPODLEGŁOŚCI 4, 60-874, POZNAŃ - POLAND

Święto Duan w złota jesień 金秋端節
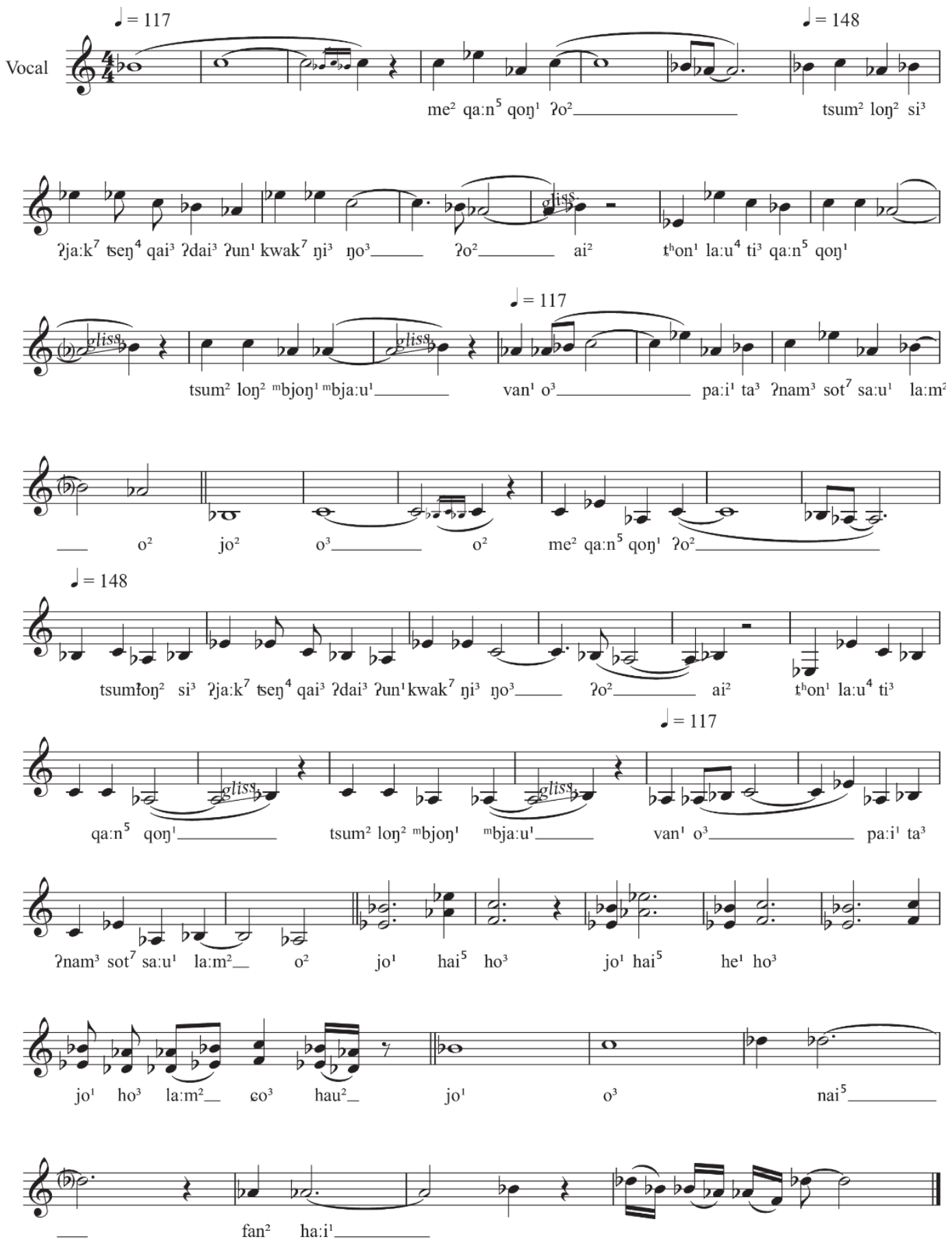
INVESTIGATIONES LINGUISTICAE VOL. XXXVI, 2017

(C) INSTITUTE OF LINGUISTICS - ADAM MICKIEWICZ UNIVERSITY

AL. NIEPODLEGŁOŚCI 4, 60-874, POZNAŃ - POLAND
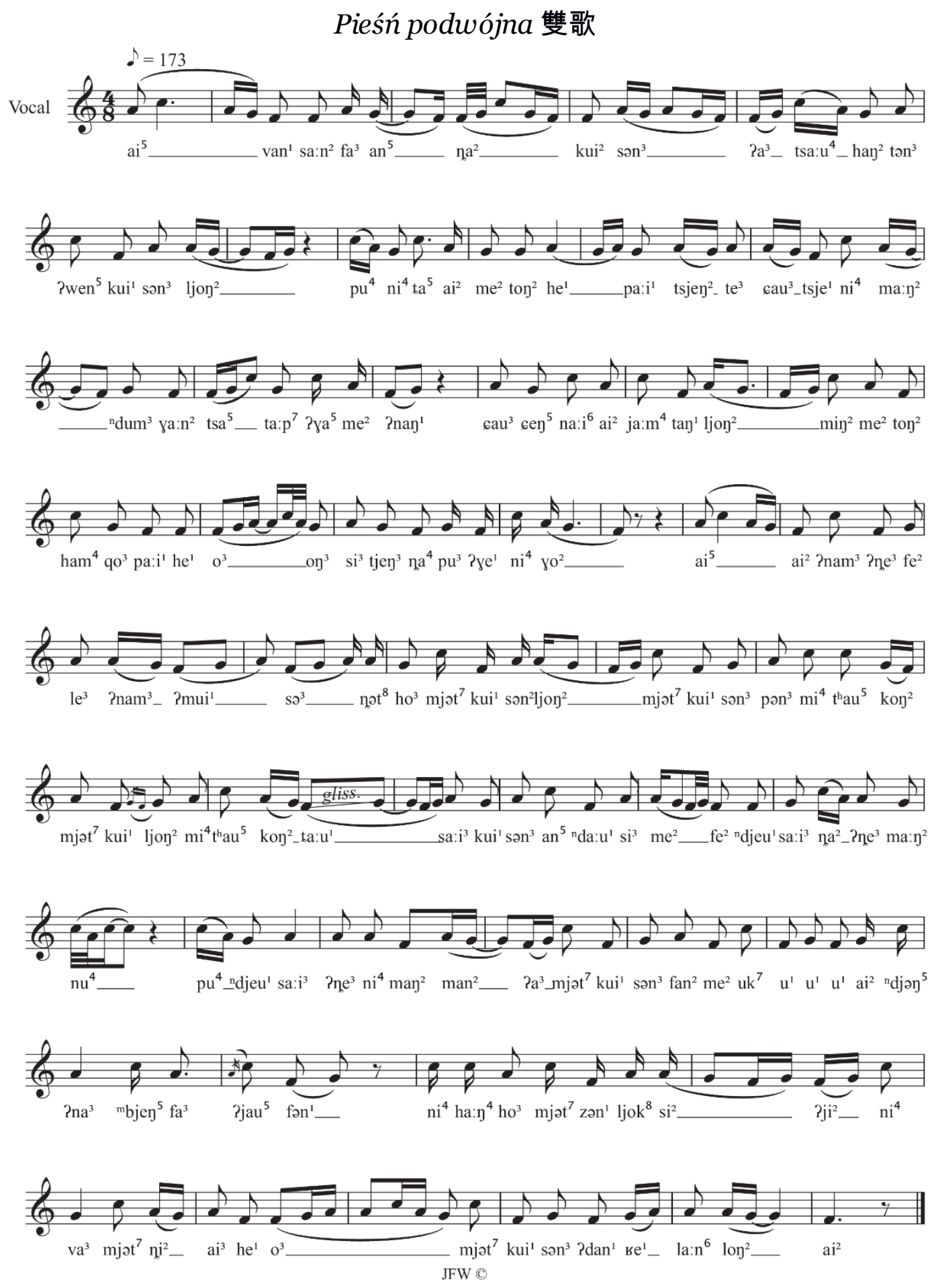
INVESTIGATIONES LINGUISTICAE VOL. XXXVI, 2017

(C) INSTITUTE OF LINGUISTICS - ADAM MICKIEWICZ UNIVERSITY

AL. NiEPODLEgŁOŚCI 4, 60-874, POZNAŃ - POLAND

\section{Pieśn toastowa 敬酒歌}
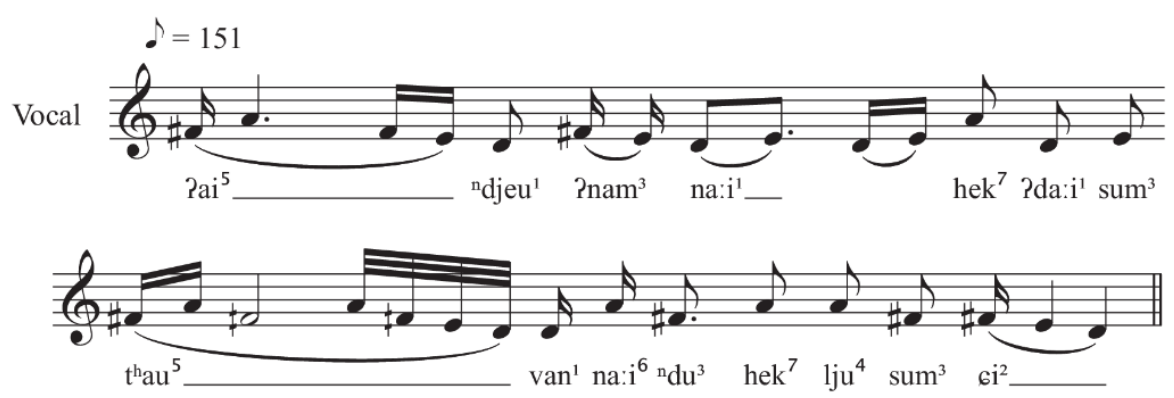

$A=225$
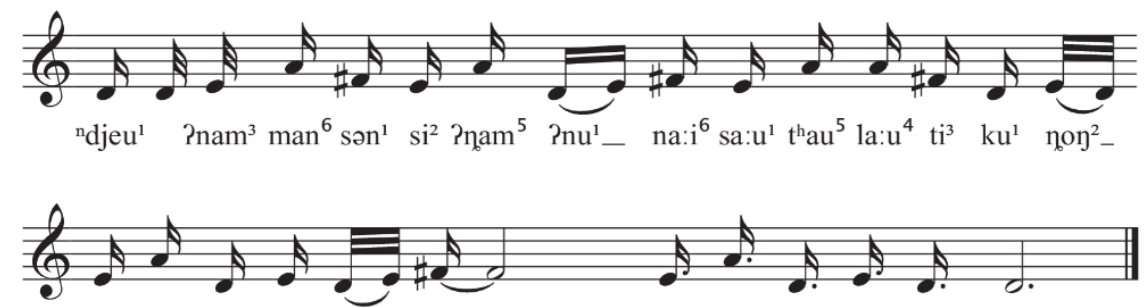

$\mathrm{qo}^{3}$ hek $^{7} \operatorname{sjen}^{1}$ von $^{2} \mathrm{a}^{1} \_$vai $^{3}-$

$\mathrm{qo}^{3}$ hek $^{7}$ sjen $^{1}$ von $^{2} \quad \mathrm{a}^{1} \quad$ vai $^{3}$

JFW $\mathcal{O}$ 